\title{
Modified Gravitational Search Algorithm for Energy Demand Estimation of Turkey
}

\author{
Mehmet BEŞKİRLi ${ }^{1 *}$, Mehmet Fatih TEFEK ${ }^{2}$, Harun UĞUZ ${ }^{3}$ \\ ${ }^{1}$ Şirnak University, Department of Computer Engineering, Sirnak, Turkey \\ ${ }^{2}$ Osmaniye Korkut Ata University, Department of Computer Engineering, Osmaniye, Turkey \\ ${ }^{3}$ Konya Technical University, Department of Computer Engineering, Konya, Turkey \\ (ORCID: 0000-0002-4842-3817) (ORCID: 0000-0003-3390-4201) (ORCID: 0000-0003-4617-202X)
}

\begin{abstract}
Estimation of energy demand beforehand is a quite significant problem in respect of economy and sources of country. In this study, Gravitational Search Algorithm (GSA) was modified by making some innovations in GSA and called as Modified Gravitational Search Algorithm (MGSA). Energy demand estimation is conducted through the relationship between the increase in economic indicators in Turkey and energy consumption. Estimation was actualized by using gross domestic product (GSYH), importation, exportation and demography for energy demand estimation and both linear and exponential equations. Energy demand between the years 2017-2037 was predicted by using the data belong to 1997-2011. The years between 2012 and 2016 were used as test data. It was observed that the results acquired via MGSA estimate better compared to GSA results.
\end{abstract}

Anahtar kelimeler: Gravitational search algorithm, Energy demand, Estimation, Turkey.

\section{Türkiye'nin Enerji Talebi Tahmini için Modifiye Yerçekimi Arama Algoritması}

\begin{abstract}
$\ddot{O} \mathbf{z}$
Ülke ekonomisi ve kaynakları bakımından enerji talebini önceden tahmin etmek çok önemli bir problemdir. Bu çalışmada, Yerçekimi Arama Algoritması (YAA) ile YAA'da yapılan bazı yenilikler yapılarak modifiye edilmiş ve Modifiye Yerçekimi Arama Algoritması (MYAA) olarak adlandırılmıştır. Enerji talep tahmini, Türkiye'deki ekonomik göstergelerin artışı ile enerji tüketimi arasındaki ilişki ile gerçekleşmektedir. Enerji talep tahmini için gayri safi yurtiçi hasıla (GSYH), ithalat, ihracat ve nüfus bilgileri hem lineer hem de üssel denklemler kullanılarak tahmin işlemi gerçekleştirildi. 1997-2011 yılları arasındaki veriler kullanılarak 2017-2037 yılları arasındaki enerji talebi tahmin edilmiştir. 2012 ile 2016 yılları ise test verisi olarak kullanılmıştır. MGSA ile elde edilen sonuçlar GSA sonuçlarına göre daha iyi bir tahmin gerçekleştirdiği görülmüştür.
\end{abstract}

Keywords: Yerçekimi arama algoritması, Enerji talebi, Tahmin, Türkiye.

\section{Introduction}

Being an indicator of economic and social development from past till today in all phases of life, energy still continues to be an indispensible energy factor [1]. Furthermore, countries may need more energy together with the developments in the field of industry. Therefore, energy analysis and policies determine the amount of energy needed by countries [2]. As energy becomes a source, importance of which consistently increase and which becomes more of importance in life, determination of estimation of amount of energy to be consumed plays a substantial role [3]. Being significant for all developed and developing countries, energy demand estimation is also important for Turkey, having part among developing countries [4]. It is necessary to arrange energy demand in a good manner in long term for a

"Sorumlu yazar: mehmetbes@sirnak.edu.tr

Geliş Tarihi: 15.12.2019, Kabul Tarihi: 24.09.2019 
powerful Turkish economy. Energy production becomes cheaper because of the increase in energy production with domestic opportunities currently; however, this case shall be dealt in a manner that it will not lead to energy waste. In case of wrong calculations on estimation of prospective energy demand, the country may have serious problems due to deficient energy production or available sources are wasted in case of over production. Relationship between energy consumption and income was established by means of various mathematical formulas or various techniques for estimation of this procedure and thereby various models were formed to estimate primary energy demand of Turkey. These studies were conducted basing on statistical techniques [5-10], artificial intelligence techniques [11-13] and intuitional techniques [1, 4, 14-21].

\section{Gravitational Search Algorithm (GSA)}

GSA method is a physics based optimization algorithm designed by Rashedi et al. [22]. GSA was inspired by Newton's laws on gravity and inertia. Each particle in search universe in GSA is accepted as a mass. All masses in search universe pull one another according to Newton's law of universal gravitation and apply force to one another with force of gravity. The result with the biggest mass in search universe pulls other results towards it and affects them. In this manner, search universe is pulled towards global minimum and most appropriate solution can be reached.

GSA is comprised of following steps:

If $N$ is assumed as a system with mass, position of the masses are randomly determined first of all. $i$. Position of the mass is defined as in equation 1.

$X_{i}=\left(x_{i}^{1}, \ldots, x_{i}^{d}, \ldots, x_{i}^{n}\right) \quad i=1,2, \ldots, N$

Here, $n$ defines the size of the problem, $x_{i}^{d} i$. position of the mass in $d$. in dimension. Force effect of $i$ mass from $j$ mass at a certain $t$ time is defined as in equation 2.

$F_{i j}^{d}(t)=G(t) \frac{M_{p i}(t) M_{a j}(t)}{R_{i j}(t)+\varepsilon}\left(x_{j}^{d}(t)-x_{i}^{d}(t)\right)$

Here, $M_{a j}$ shows active gravity mass of $j$ mass; $M_{p i}$ shows passive gravity mass of $i$ mass; $\varepsilon$ shows a constant defined by user, $x_{j}^{d}(t)$ and $x_{i}^{d}(t)$ show positions of $i$ and $j$ masses at $d$. dimension at a certain $t$ time; $R_{i j}(t)$ shows the distance between $i$ and $j$ masses at $t$ time. $G(t)$ is gravity constant at $t$ time and formula was given in equation 3 .

$G(t)=G_{0} \exp \left(-\alpha \frac{t}{T}\right)$

Here, $G_{0}$ shows initial value of gravity constant randomly selected; $\alpha$ shows the constant value defined by user; $t$ shows the iteration value at that time and $T$ shows maximum number of iteration. Total forces affecting $i$ mass at $d$. size is calculated as in equation 4 .

$F_{i}^{d}(t)=\sum_{j=1, j \neq i}^{N} \operatorname{rand}_{j} F_{i j}^{d}(t)$

Here, rand $_{j}$ is a random figure varying between $[0,1]$ range. According to Newton's law on acceleration, acceleration of $i$ mass at $d$. size to activate the mass depending on the total force in equation 4 is given in Equation 5 .

$a_{i}^{d}(t)=\frac{F_{i}^{d}(t)}{M_{i i}(t)}$ 
Here, $M_{i i}$ value shows inertia mass of $i$ agent. Depending on acceleration value, speed of the mass at $d$. size is updated as in Equation 6 and position is updated depending on the speed as in Equation 7.

$v_{i}^{d}(t+1)=\operatorname{rand}_{i} v_{i}^{d}(t)+a_{i}^{d}(t)$

$x_{i}^{d}(t+1)=x_{i}^{d}(t)+v_{i}^{d}(t+1)$

Here, rand $_{i}$ is a random value varying between $[0,1]$. When algorithm interruption criterion is provided, the mass being most appropriate for the objective function is selected for solution.

\section{Proposed Modified Gravitational Search Algorithm (MGSA)}

Position of the mass is determined randomly in standard GSA as in equation 1. As a result of this random determination in first search universe, positions of the masses may be too far from one another. This may result in convergence to optimum result in a much more number of iteration in solution of problem. It is required that the positions of the masses shall be closer and homogeneous distribution with the purpose of achieving optimum result at shorter operating time and less iteration. For this, modified GSA (MGSA) was designed by adding w, as in equation 1 and equation 7, being a linear decreasing inertia weight [23] function as in equation 8.

$w=w_{\max }-\frac{w_{\max }-w_{\min }}{\text { Iter }_{\max }} \times k$

In Equation 8, $\mathrm{w}_{\max }$ and $\mathrm{w}_{\min }$ refer to constant values varying between 0.9 and 0.1 and refers

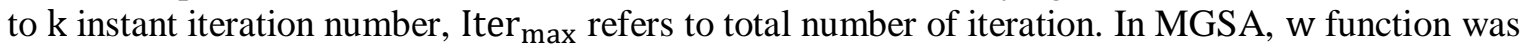
applied as in equation 9 and equation 10.

$X_{i}=w\left(x_{i}^{1}, \ldots, x_{i}^{d}, \ldots, x_{i}^{n}\right)$

$x_{i}^{d}(t+1)=w x_{i}^{d}(t)+v_{i}^{d}(t+1)$

It was provided that MGSA searches global optimum result at less iteration through Equation 9 and 10. In this manner, it was targeted to converge the optimum result among the solutions rather than making search far and wide in search universe.

\section{Test Functions}

Ten different test functions were used in this study. These are given in Table 1, function names, formulation, values of the search space range, characteristics and minimum values, respectively. 
Table 1. Test functions D: Dimension U: Unimodal M: Multimodal F: Feature

\begin{tabular}{|c|c|c|c|c|}
\hline Function & Formulation & Search Space & $\mathrm{F}$ & $f_{\min }$ \\
\hline Sphere & $F_{1}(x)=\sum_{i=1}^{D} x_{i}^{2}$ & {$[-100,100]^{\mathrm{D}}$} & $\mathrm{U}$ & 0 \\
\hline Schwefel 2.22 & $F_{2}(x)=\sum_{\mathrm{i}=1}^{D}\left|x_{i}\right|+\prod_{i=1}^{D}\left|x_{i}\right|$ & {$[-10,10]^{\mathrm{D}}$} & $\mathrm{U}$ & 0 \\
\hline Schwefel 1.2 & $F_{3}(x)=\sum_{i=1}^{D}\left(\sum_{j=1}^{i} x_{j}\right)^{2}$ & {$[-100,100]^{\mathrm{D}}$} & $\mathrm{U}$ & 0 \\
\hline Schwefel 2.21 & $F_{4}(x)=\max \left\{\left|x_{i}\right|, 1 \leq i \leq D\right\}$ & {$[-100,100]^{\mathrm{D}}$} & $\mathrm{U}$ & 0 \\
\hline Rosenbrock & $F_{5}(x)=\sum_{i=1}^{D-1}\left[100\left(x_{i+1}-x_{i}^{2}\right)^{2}+\left(x_{i}-1\right)^{2}\right]$ & {$[-30,30]^{\mathrm{D}}$} & $\mathrm{U}$ & 0 \\
\hline Schwefel & $F_{6}(x)=\sum_{i=1}^{D}-x_{i} \sin \left(\sqrt{\left|x_{i}\right|}\right)$ & {$[-500,500]^{\mathrm{D}}$} & M & $-12569,5$ \\
\hline Rastrigin & $F_{7}(x)=\sum_{i=1}^{D}\left[x_{i}^{2}-10 \cos \left(2 \pi x_{i}\right)+10\right]$ & {$[-5,12,5,12]^{\mathrm{D}}$} & M & 0 \\
\hline Ackley & $\begin{aligned} F_{8}(x)=-20 \exp ( & \left.-0,2 \sqrt{\frac{1}{D} \sum_{i=1}^{D} x_{i}^{2}}\right) \\
& -\exp \left(\frac{1}{D} \sum_{i=1}^{D} \cos \left(2 \pi x_{i}\right)\right)+20+e\end{aligned}$ & {$[-32,32]^{\mathrm{D}}$} & M & 0 \\
\hline Griewank & $F_{9}=\frac{1}{4000} \sum_{i=1}^{D} x_{i}^{2}-\prod_{i=1}^{D} \cos \left(\frac{x_{i}}{\sqrt{i}}\right)+1$ & {$[-600,600]^{\mathrm{D}}$} & M & 0 \\
\hline Penalized & $\begin{array}{l}F_{10}(x)=\frac{\pi}{D}\left\{10 \sin ^{2}\left(\pi y_{1}\right)+\sum_{i=1}^{D-1}\left(y_{i}-1\right)^{2}\left[1+10 \sin ^{2}\left(\pi y_{i+1}\right)\right]\right. \\
\left.\quad+\left(y_{D}-1\right)^{2}\right\}+\sum_{i=1}^{D} u\left(x_{i}, 10,100,4\right) \\
y_{i}=1+\frac{1}{4}\left(x_{i}+1\right) \\
u\left(x_{i}, a, k, m\right)=\left\{\begin{array}{c}k\left(x_{i}-a\right)^{m} x_{i}>a \\
0-a<x_{i}<a \\
k\left(-x_{i}-a\right)^{m} x_{i}<-a\end{array}\right.\end{array}$ & {$[-50,50]^{\mathrm{D}}$} & M & 0 \\
\hline
\end{tabular}

\section{Analysis of Test Functions}

For ten different test functions, the number of populations was taken as 50 and the problem size was taken as 30 and each test function was run thirty times independently. The results are given in Table 2 .

Table 2. The analysis results of ten different test functions

\begin{tabular}{|l|l|c|c|}
\hline \multicolumn{2}{|l|}{ Function } & \multicolumn{1}{|c|}{ GSA } & MGSA \\
\hline \multirow{4}{*}{$\mathrm{F}_{1}$} & Best & $2.8435 \mathrm{e}-17$ & $2.3343 \mathrm{e}-43$ \\
\cline { 2 - 4 } & Mean & $8.4468 \mathrm{e}-17$ & $\mathbf{1 . 5 8 7 5 e}-42$ \\
\cline { 2 - 4 } & Worst & $1.4902 \mathrm{e}-16$ & $4.0350 \mathrm{e}-42$ \\
\cline { 2 - 4 } & Std. S. & $2.9470 \mathrm{e}-17$ & $8.3720 \mathrm{e}-43$ \\
\hline \multirow{4}{*}{$\mathrm{F}_{2}$} & Best & $3.3117 \mathrm{e}-08$ & $1.6170 \mathrm{e}-21$ \\
\cline { 2 - 4 } & Mean & $4.5278 \mathrm{e}-08$ & $\mathbf{3 . 8 7 9 5 e}-21$ \\
\cline { 2 - 4 } & Worst & $6.3573 \mathrm{e}-08$ & $5.7226 \mathrm{e}-21$ \\
\cline { 2 - 4 } & Std. S. & $7.6129 \mathrm{e}-09$ & $1.0101 \mathrm{e}-21$ \\
\hline \multirow{5}{*}{$\mathrm{F}_{3}$} & Best & $7.1512 \mathrm{e}+01$ & $6.1911 \mathrm{e}-43$ \\
\cline { 2 - 4 } & Mean & $2.7875 \mathrm{e}+02$ & $\mathbf{2 . 5 3 2 1 e}-42$ \\
\cline { 2 - 4 } & Worst & $5.7872 \mathrm{e}+02$ & $6.5421 \mathrm{e}-42$ \\
\cline { 2 - 4 } & Std. S. & $1.0845 \mathrm{e}+02$ & $1.4165 \mathrm{e}-42$ \\
\hline \multirow{4}{*}{$\mathrm{F}_{4}$} & Best & $4.7688 \mathrm{e}-09$ & $2.2885 \mathrm{e}-22$ \\
\cline { 2 - 4 } & Mean & $6.6455 \mathrm{e}-09$ & $\mathbf{6 . 5 0 4 1 e}-22$ \\
\cline { 2 - 4 } & Worst & $1.0165 \mathrm{e}-08$ & $9.1134 \mathrm{e}-22$ \\
\cline { 2 - 4 } & Std. S. & $1.3713 \mathrm{e}-09$ & $1.2608 \mathrm{e}-22$ \\
\hline
\end{tabular}




\begin{tabular}{|l|l|c|c|}
\hline \multirow{4}{*}{$\mathrm{F}_{5}$} & Best & $2.5571 \mathrm{e}+01$ & $2.8706 \mathrm{e}+01$ \\
\cline { 2 - 4 } & Mean & $2.9380 \mathrm{e}+01$ & $\mathbf{2 . 8 7 8 3 e + 0 1}$ \\
\cline { 2 - 4 } & Worst & $1.3111 \mathrm{e}+02$ & $2.8808 \mathrm{e}+01$ \\
\cline { 2 - 4 } & Std. S. & $1.9214 \mathrm{e}+01$ & $2.1880 \mathrm{e}-02$ \\
\hline \multirow{4}{*}{$\mathrm{F}_{6}$} & Best & $-3.7929 \mathrm{e}+03$ & $-3.7277 \mathrm{e}+03$ \\
\cline { 2 - 4 } & Mean & $\mathbf{- 2 . 8 1 9 4 e + 0 3}$ & $-2.5657 \mathrm{e}+03$ \\
\cline { 2 - 4 } & Worst & $-2.0244 \mathrm{e}+03$ & $-1.9966 \mathrm{e}+03$ \\
\cline { 2 - 4 } & Std. S. & $4.4020 \mathrm{e}+02$ & $4.2976 \mathrm{e}+02$ \\
\hline \multirow{5}{*}{$\mathrm{F}_{7}$} & Best & $7.9597 \mathrm{e}+00$ & $0.0000 \mathrm{e}+00$ \\
\cline { 2 - 4 } & Mean & $1.5986 \mathrm{e}+01$ & $\mathbf{0 . 0 0 0 0 e + 0 0}$ \\
\cline { 2 - 4 } & Worst & $2.8854 \mathrm{e}+01$ & $0.0000 \mathrm{e}+00$ \\
\cline { 2 - 4 } & Std. S. & $5.2384 \mathrm{e}+00$ & $0.0000 \mathrm{e}+00$ \\
\hline \multirow{5}{*}{$\mathrm{F}_{8}$} & Best & $4.7232 \mathrm{e}-09$ & $8.8818 \mathrm{e}-16$ \\
\cline { 2 - 4 } & Mean & $7.0974 \mathrm{e}-09$ & $\mathbf{8 . 8 8 1 8 e}-16$ \\
\cline { 2 - 4 } & Worst & $9.4370 \mathrm{e}-09$ & $8.8818 \mathrm{e}-16$ \\
\cline { 2 - 4 } & Std. S. & $9.8758 \mathrm{e}-10$ & $0.0000 \mathrm{e}+00$ \\
\hline \multirow{5}{*}{$\mathrm{F}_{9}$} & Best & $0.0000 \mathrm{e}+00$ & $0.0000 \mathrm{e}+00$ \\
\cline { 2 - 4 } & Mean & $2.6378 \mathrm{e}-02$ & $\mathbf{0 . 0 0 0 0 e + 0 0}$ \\
\cline { 2 - 4 } & Worst & $1.0736 \mathrm{e}-01$ & $0.0000 \mathrm{e}+00$ \\
\cline { 2 - 4 } & Std. S. & $3.1403 \mathrm{e}-02$ & $0.0000 \mathrm{e}+00$ \\
\hline \multirow{5}{*}{$\mathrm{F}_{10}$} & Best & $3.0035 \mathrm{e}-19$ & $2.1261 \mathrm{e}-01$ \\
\cline { 2 - 4 } & Mean & $\mathbf{3 . 1 1 2 6 e}-\mathbf{0 2}$ & $3.3457 \mathrm{e}-01$ \\
\cline { 2 - 4 } & Worst & $5.1912 \mathrm{e}-01$ & $5.9922 \mathrm{e}-01$ \\
\cline { 2 - 4 } & Std. S. & $1.0254 \mathrm{e}-01$ & $8.7988 \mathrm{e}-02$ \\
\hline \multirow{5}{*}{} & & & \\
\hline
\end{tabular}

In Table 2, ten functions were solved by both GSA and MGSA. When the average value of each solution result was examined, MGSA was successful in eight functions and GSA was successful in two functions. Thus, MGSA performed better than GSA.

After analyzing the function results, Wilcoxon statistical test was applied on the results. The statistical analysis results obtained are given in Table 3.

Table 3. The analysis results of Wilcoxon test

\begin{tabular}{|c|c|}
\hline & $\begin{array}{c}\text { GSA-MGSA } \\
f_{1}-f_{10}\end{array}$ \\
\hline p-value & $4.51 \mathrm{E}-02$ \\
\hline
\end{tabular}

Wilcoxon means that there is a significant difference if the statistical analysis result is less than 0.05. if it is above 0.05 it means that there is no significant difference. When we look at Table 3, it is seen that there is a significant difference between the modified algorithm results and the original algorithm results, since the value obtained in the statistical test is below the critical value.

\section{Applications of Energy Demand Estimation Via MGSA}

MGSA-linear $\left(M G S A_{L}\right)$ and MGSA-exponential $\left(M G S A_{E}\right)$ models were created basing on socioeconomic indicators between 1997-2016 years. Equations of the models formed in (11) and (12) equilibriums are given below. 
$G S A_{L}=w_{1} \cdot X_{1}+w_{2} \cdot X_{2}+w_{3} \cdot X_{3}+w_{4} \cdot X_{4}+w_{0}$

$G S A_{E}=w_{1} \cdot X_{1}^{w_{2}}+w_{3} \cdot X_{2}^{w_{4}}+w_{5} \cdot X_{3}^{w_{6}}+w_{7} \cdot X_{4}^{w_{8}}+w_{0}$

$w_{i}(i \in[0,4])$ in Eq. (11) and $w_{i}(i \in[0,8])$ in Eq. (12) are the weight values calculated by the GSA. These weight values are unconstrained $\left(-\infty \leq w_{i} \leq+\infty\right) . X_{1}, X_{2}, X_{3}$ and $X_{4}$ are the population, GDP, import and export values, respectively.

Table 4. Energy demand between 1997-2016 and indicators

\begin{tabular}{cccccc}
\hline Years & $\begin{array}{c}\text { Energy demand } \\
\text { (MTOE) }\end{array}$ & $\begin{array}{c}\text { Population } \\
106\end{array}$ & $\begin{array}{c}\text { GDP } \\
109(\$)\end{array}$ & $\begin{array}{c}\text { Importation } \\
109(\$)\end{array}$ & $\begin{array}{c}\text { Exportation } \\
109(\$)\end{array}$ \\
\hline 1997 & 73.78 & 61.58 & 253.71 & 48.56 & 26.26 \\
1998 & 74.71 & 62.46 & 270.95 & 45.92 & 26.97 \\
1999 & 76.77 & 63.36 & 247.54 & 40.67 & 26.59 \\
2000 & 80.5 & 64.73 & 265.38 & 54.5 & 27.77 \\
2001 & 75.4 & 65.6 & 196.74 & 41.4 & 31.33 \\
2002 & 78.33 & 66.4 & 230.49 & 51.55 & 36.06 \\
2003 & 83.84 & 67.19 & 304.9 & 69.34 & 47.25 \\
2004 & 87.82 & 68.01 & 390.39 & 97.54 & 63.17 \\
2005 & 91.58 & 68.86 & 481.5 & 116.77 & 73.48 \\
2006 & 99.59 & 69.73 & 526.43 & 139.58 & 85.53 \\
2007 & 107.63 & 70.59 & 648.75 & 170.06 & 107.27 \\
2008 & 106.27 & 71.52 & 742.09 & 201.96 & 132.03 \\
2009 & 102.92 & 72.56 & 616.7 & 140.93 & 102.14 \\
2010 & 105.83 & 73.72 & 731.61 & 185.54 & 113.88 \\
2011 & 114.48 & 74.72 & 773.98 & 240.84 & 134.91 \\
2012 & 120.09 & 75.63 & 786.28 & 236.55 & 152.46 \\
2013 & 120.29 & 76.67 & 823.04 & 251.66 & 151.8 \\
2014 & 123.94 & 77.7 & 800.11 & 242.18 & 157.61 \\
2015 & 126.94 & 78.74 & 861.46 & 207.23 & 143.84 \\
2016 & 129.24 & 79.82 & 862.74 & 198.62 & 142.53 \\
\hline
\end{tabular}

These models formed were applied to make the root mean square error (RMSE), being the objective function, minimum. Data of 75\% between 1997-2011 was used for training purposes and data of 25\% between 2012-2016 for test purposes. Min RMSE was provided in Equation (13).

$$
\min R M S E=\left[\frac{1}{n} \sum_{i=1}^{n}\left(y_{o}-y_{p}\right)^{2}\right]^{\frac{1}{2}}
$$

G0 value was taken as 20 , $\alpha$ value as 100 , mass number as 50 , iteration number as 1000 for MGSA and GSA. All algorithms were activated for 30 times and weights were calculated as per the value making RMSE value minimum. Comparison of the models was shown in Table 5 by min RMSE conclusions. MGSA method calculated min RMSE value lower in test results compared to linear and exponential estimation models in Table 5. Convergence curve of linear and exponential estimation models are seen in Figure 1 and Figure 2.

Weight values for linear estimation:

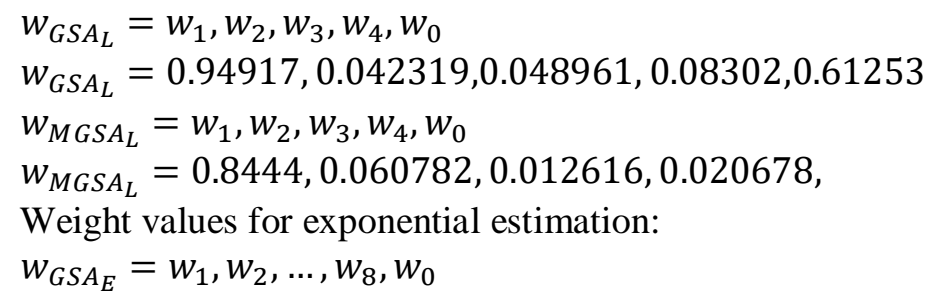




$$
\begin{aligned}
& w_{G S A_{E}}=-2.7815,-2.8483,4.966,0.44316, \\
& w_{M G S A_{E}}=w_{1}, w_{2}, \ldots, w_{8}, w_{0} \\
& w_{M G S A_{E}}=0.0040895,2.3645,-0.00068864,-0.00033574,0.0013665,1.433,-6.654 e-05, \\
& 0.00018682,0.00072226
\end{aligned}
$$

Table 5. Min RMSE results for linear and exponential models

\begin{tabular}{lccc}
\hline \multirow{2}{*}{ Models } & & $\begin{array}{c}\text { Training set }(75 \%) \\
(1997-2011)\end{array}$ & $\begin{array}{c}\text { Testing set (25\%) } \\
(2012-2016)\end{array}$ \\
\cline { 3 - 4 } & & RMSE & RMSE \\
\hline \multirow{2}{*}{ Linear } & $\left(G S A_{L}\right)$ & 7.0383931435 & 9.1886921300 \\
& $\left(M G S A_{L}\right)$ & 5.3226597211 & 2.7983117641 \\
\multirow{2}{*}{ Exponential } & $\left(G S A_{E}\right)$ & 4.5094487411 & 4.7251591706 \\
& $\left(M G S A_{E}\right)$ & 3.9470073355 & 1.8124215981 \\
\hline
\end{tabular}

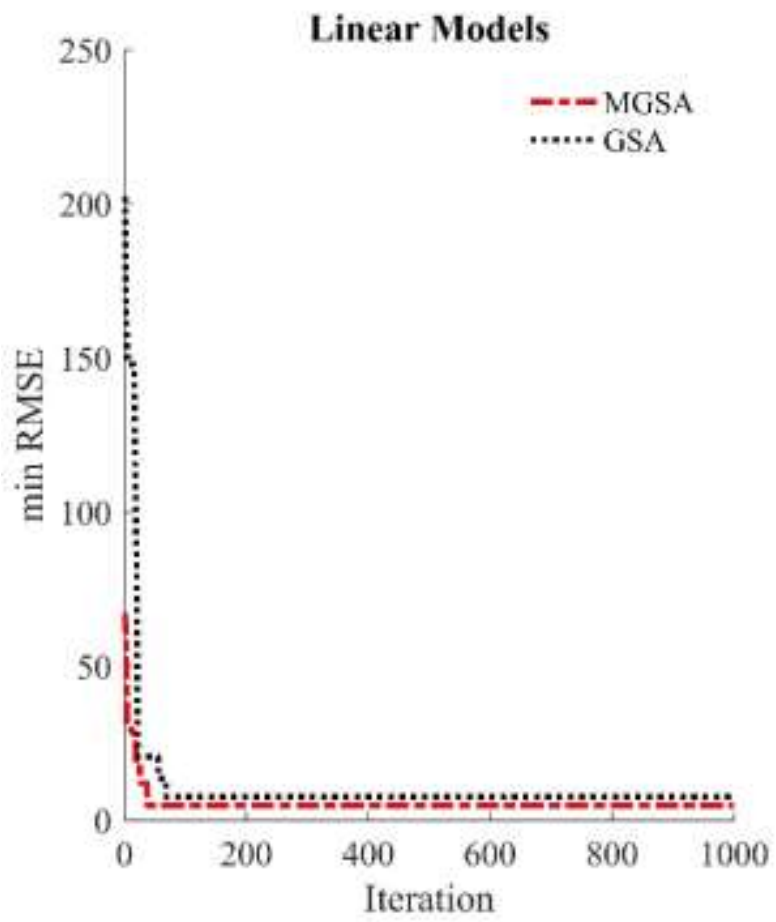

Figure 1. MGSA and GSA linear estimation model convergence curve 


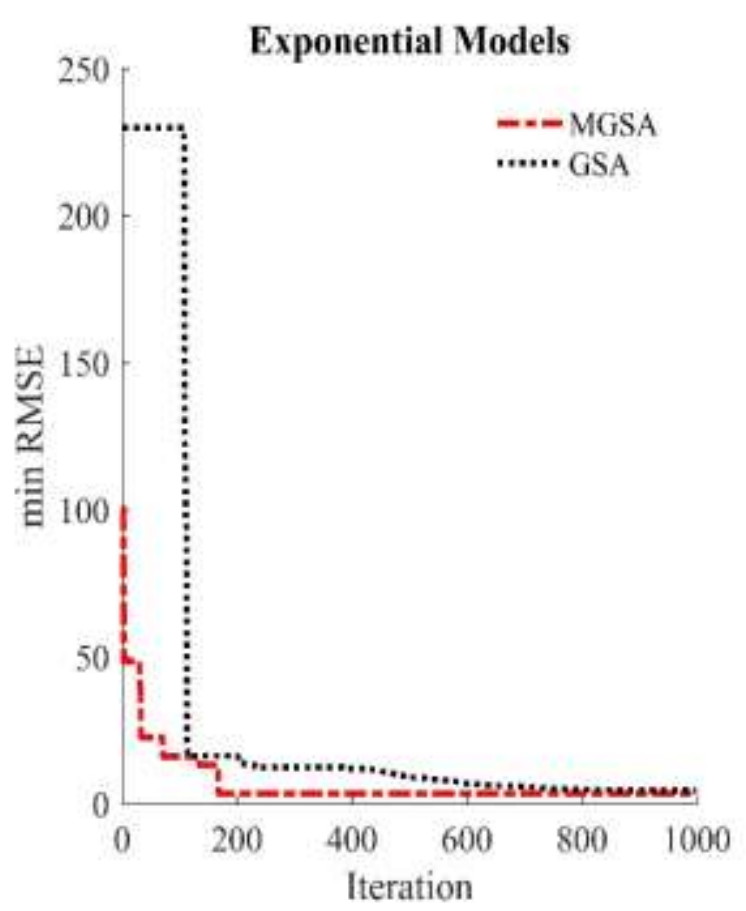

Figure 2. MGSA and GSA Exponential estimation model convergence curve

The values estimated by means of the actual values between 1997 and 2016 are provided in Figure 3. 1997-2011 were shown for training and 2012-2016 for test purposes. When the test results in Figure 3 are handled, it is observed that MGSAE energy estimation and actualized energy demand value coincide. It is observed in Figure 3 that the difference between the value calculated with GSAL and actual energy demand is high.

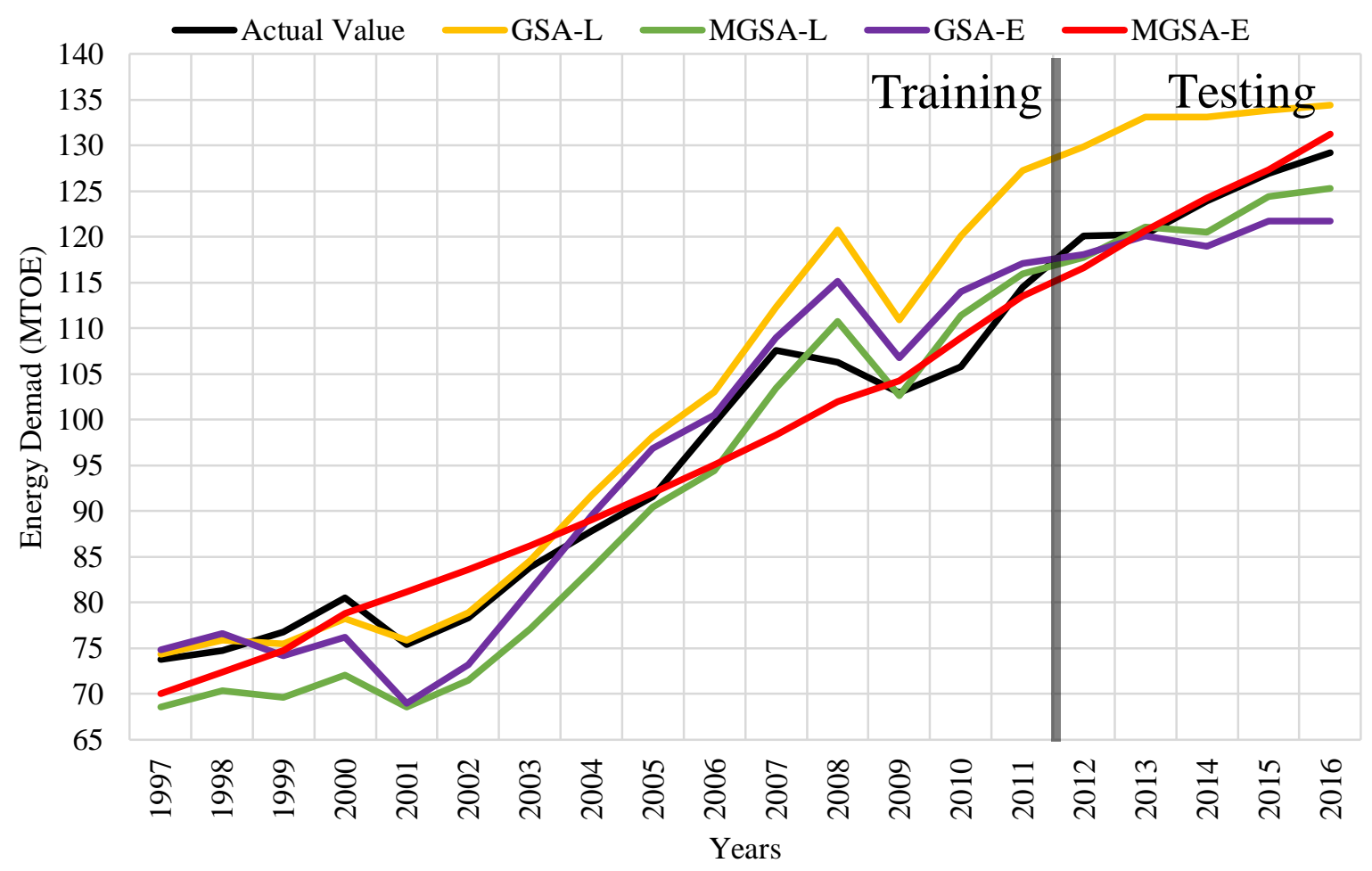

Figure 3. Estimations of the models developed with actual values between the years 1997 and 2016 


\subsection{Scenarios and Estimation}

Scenario studies were conducted for 21-years term between 2017 and 2037. Low, expected and high probability scenarios were established for energy demand estimation. Medium-term estimation increase rates of Ministry of Development (MOD) were taken for GDP in all scenarios [24]. Data on population were received from Turkish Statistical Institute (TSI) [25]. Expected scenario was formed by taking mean increase or decrease rates actualized in last 10 years for importation and exportation. Importation and exportation data in low and medium probability scenarios was determined as 1.5 points more or less than the expected scenario. Scenarios were given in Table 6.

Table 6. Scenario settings

\begin{tabular}{|c|c|c|c|c|}
\hline \multirow{2}{*}{ Scenarios } & GDP & Population & Import & Export \\
\hline & \multicolumn{4}{|c|}{ Growth rate per year $(\%)$} \\
\hline Low & $4 \%$ & & $3.9 \%$ & $4.7 \%$ \\
\hline Expected & $4.5 \%$ & $\begin{array}{c}\text { The population data } \\
\text { obtained from }\end{array}$ & $5.4 \%$ & $6.2 \%$ \\
\hline High & $5 \%$ & TURKSTAT [26] & $6.9 \%$ & $7.7 \%$ \\
\hline
\end{tabular}

MGSAE model, developed for estimations studies was used for the scenarios created. The reason for selecting MGSAE model was the parallelism between min RMSE error in test results in Table 5 and actual values in Figure 2. Estimation results were indicated in Table 7. Estimation results calculated with MGSAE model were given in Figure 4.

Table 7. Energy demand estimation results between the years 2017 and 2037 through MGSAE model

\begin{tabular}{cccc}
\hline \multicolumn{4}{c}{ MGSAE $^{3} \begin{array}{c}\text { Model Estimation Results (MTOE) } \\
\text { Scenarios }\end{array}$} \\
\hline Years & Low & Expected & High \\
\hline 2017 & 128.46 & 128.81 & 129.15 \\
2018 & 131.79 & 132.51 & 133.23 \\
2019 & 135.17 & 136.30 & 137.44 \\
2020 & 138.66 & 140.22 & 141.83 \\
2021 & 142.24 & 144.29 & 146.40 \\
2022 & 145.93 & 148.50 & 151.16 \\
2023 & 149.74 & 152.86 & 156.13 \\
2024 & 153.64 & 157.38 & 161.30 \\
2025 & 157.65 & 162.04 & 166.68 \\
2026 & 161.77 & 166.87 & 172.30 \\
2027 & 166.02 & 171.87 & 178.16 \\
2028 & 170.39 & 177.06 & 184.28 \\
2029 & 174.88 & 182.43 & 190.67 \\
2030 & 179.50 & 188.00 & 197.34 \\
2031 & 184.26 & 193.77 & 204.30 \\
2032 & 189.16 & 199.76 & 211.59 \\
2033 & 194.21 & 205.97 & 219.21 \\
2034 & 199.41 & 212.42 & 227.18 \\
2035 & 204.78 & 219.13 & 235.54 \\
2036 & 210.31 & 226.09 & 244.28 \\
2037 & 216.02 & 233.34 & 253.45 \\
\hline
\end{tabular}




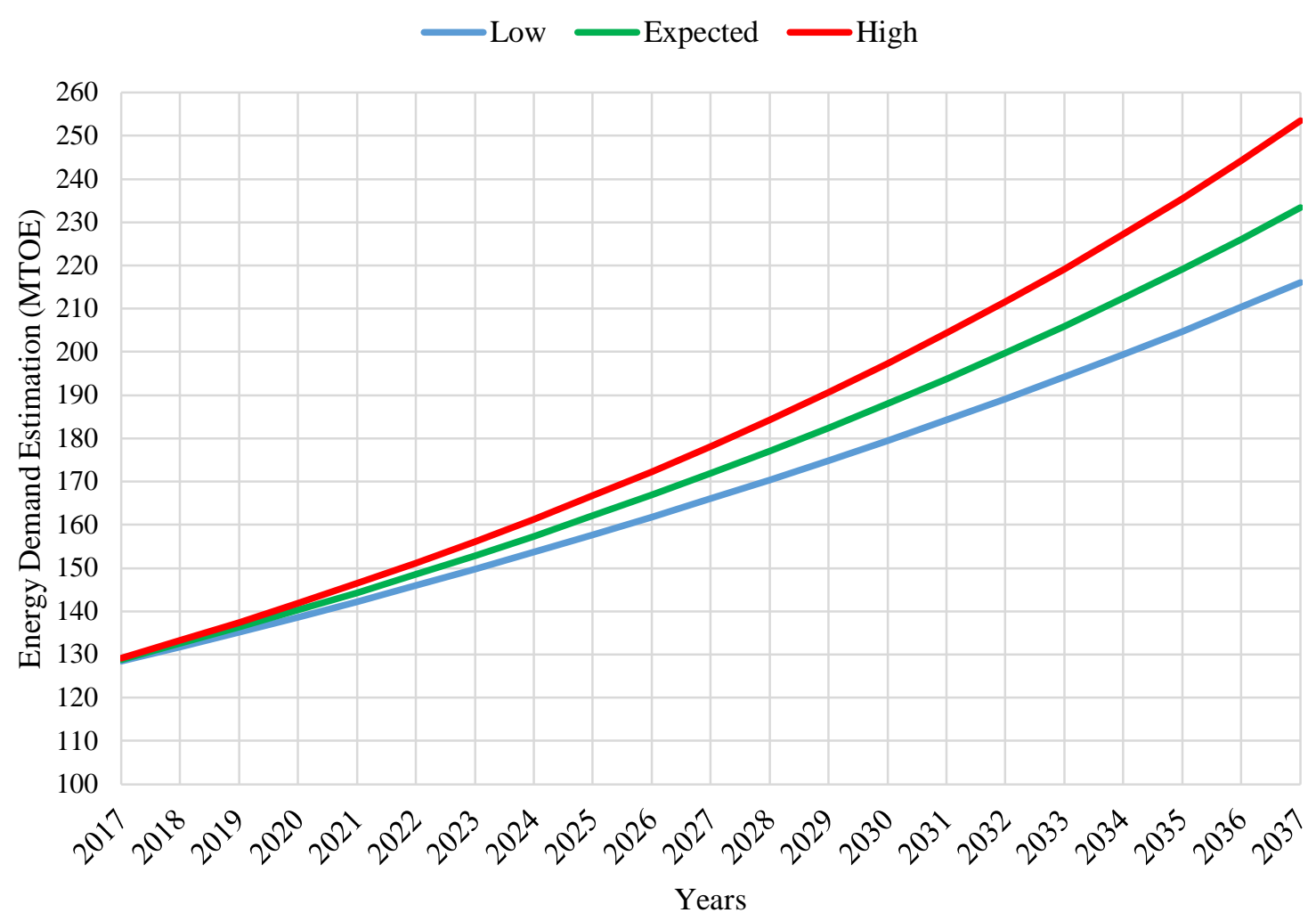

Figure 4. Energy demand estimation between 2017-2037 with MGSAE model

\section{Conclusions}

Energy demand estimation of Turkey between 2017 and 2037 was conducted in this study. Modified gravitational search algorithm (MGSA) was developed for energy demand estimation. Through MGSA developed, linear and exponential energy demand estimation models were established. The models formed were trained with population, GDP, importation and exportation data of Turkey between 1997 and 2011 and tested between 2012 and 2016. It was shown in test results that improved MGSAL and MGSAE models calculate lower RMSE error than standard GSA. When RMSE error convergence curves are analyzed, it is seen that developed MGSA method converge quicker than the GSA both in linear and exponential models. In this study, minimum RMSE value was calculated by established MGSAE model. Therefore, MGSAE model was used for estimation studies. Low, expected and high scenarios were formed for scenarios. 21-years energy demand estimation was carried out by means of MGSAE model between the years 2017 and 2037. It was observed that energy demand estimation conducted with developed MGSA method is applicable in this study.

\section{References}

[1] Beskirli M., Hakli H., Kodaz H. 2017. The energy demand estimation for Turkey using differential evolution algorithm. Sādhanā, 42 (10): 1705-1715.

[2] Dincer I., Dost S. 1996. Energy intensities for Canada. Applied Energy, 53 (3): 283-298.

[3] Aktaş E., Alioğlu O. 2012. Türkiye'de enerji sektörü analizi: Marmara bölgesi termik santraller örneği. Çukurova Üniversitesi Sosyal Bilimler Enstitüsü Dergisi, 21 (1).

[4] Toksar1 M.D. 2007. Ant colony optimization approach to estimate energy demand of Turkey. Energy Policy, 35 (8): 3984-3990.

[5] Ediger V.Ş., Akar S. 2007. ARIMA forecasting of primary energy demand by fuel in Turkey. Energy Policy, 35 (3): 1701-1708.

[6] Ediger V.Ş., Tatlidil H. 2002. Forecasting the primary energy demand in Turkey and analysis of cyclic patterns. Energy Conversion and Management, 43 (4): 473-487. 
[7] Yumurtaci Z., Asmaz E. 2004. Electric energy demand of Turkey for the year 2050. Energy Sources, 26 (12): 1157-1164.

[8] Akkurt M., Demirel O.F., Zaim S. 2016. Forecasting Turkey's natural gas consumption by using time series methods. European Journal of Economic and Political Studies, 3 (2): 1-21.

[9] Mucuk M., Uysal D. 2009. Turkey's energy demand. Current Research Journal of Social Sciences, 1 (3): 123-128.

[10] Dilaver Z., Hunt L.C. 2011. Industrial electricity demand for Turkey: a structural time series analysis. Energy Economics, 33 (3): 426-436.

[11] Sözen A., Arcaklioğlu E. 2007. Prospects for future projections of the basic energy sources in Turkey. Energy Sources, Part B, 2 (2): 183-201.

[12] Kankal M., Akpınar A., Kömürcü M.İ., Özşahin T.Ş. 2011. Modeling and Forecasting of Turkey’s Energy Consumption Using Socio-economic and Demographic Variables. Applied Energy, 88 (5): 1927-1939.

[13] Sozen A., Arcaklioglu E., Ozkaymak M. 2005. Modelling of Turkey's net energy consumption using artificial neural network. International Journal of Computer Applications in Technology, 22 (2-3): 130-136.

[14] Ceylan H., Ozturk H.K. 2004. Estimating energy demand of Turkey based on economic indicators using genetic algorithm approach. Energy Conversion and Management, 45 (15): 2525-2537.

[15] Haldenbilen S., Ceylan H. 2005. Genetic algorithm approach to estimate transport energy demand in Turkey. Energy Policy, 33 (1): 89-98.

[16] Kıran M.S., Özceylan E., Gündüz M., Paksoy T. 2012. A novel hybrid approach based on particle swarm optimization and ant colony algorithm to forecast energy demand of Turkey. Energy Conversion and Management, 53 (1): 75-83.

[17] Ünler A. 2008. Improvement of energy demand forecasts using swarm intelligence: The case of Turkey with projections to 2025. Energy Policy, 36 (6): 1937-1944.

[18] Kıran M.S., Gündüz M. 2013. A recombination-based hybridization of particle swarm optimization and artificial bee colony algorithm for continuous optimization problems. Applied Soft Computing, 13 (4): 2188-2203.

[19] Uguz H., Hakli H., Baykan O.K. 2015. A New Algorithm Based on Artificial Bee Colony Algorithm for Energy Demand Forecasting in Turkey. Paper presented at the 2015 4th International Conference on Advanced Computer Science Applications and Technologies (ACSAT).

[20] Tefek M.F., Uğuz H., Güçyetmez M. 2017. A new hybrid gravitational search-teaching-learningbased optimization method for energy demand estimation of Turkey. Neural Computing and Applications, 1-16.

[21] Tefek M.F., Harun U. 2016. Estimation of Turkey Electric Energy Demand until Year 2035 Using TLBO Algorithm. International Journal of Intelligent Systems and Applications in Engineering, 4 (Special Issue-1): 48-52.

[22] Beşkirli A., Beşkirli M., Haklı H., Uğuz H. 2018. Comparing Energy Demand Estimation Using Artificial Algae Algorithm: The Case of Turkey. Journal of Clean Energy Technologies, 6 (4).

[23] Rashedi E., Nezamabadi-Pour H., Saryazdi S. 2009. GSA: A Gravitational Search Algorithm. Information Sciences, 179 (13): 2232-2248.

[24] Xin J., Chen G., Hai Y. 2009. 24-26 April 2009. A Particle Swarm Optimizer with Multi-stage Linearly-Decreasing Inertia Weight. Paper presented at the 2009 International Joint Conference on Computational Sciences and Optimization.

[25] Beşkirli A., Özdemir D., Temurtaş H. 2019. A comparison of modified tree-seed algorithm for high-dimensional numerical functions. Neural Computing and Applications. doi:10.1007/s00521019-04155-3

[26] MOD. 2018. Medium Term Programme 2018-2020. Retrieved from http://www.mod.gov.tr/Pages/content.aspx?1=99479284-12e6-4d7d-bb4d-10d2a19feded\&i=21

[27] TSI. 2018. Main Statistics -Population and Demography. Retrieved from http://www.turkstat.gov.tr/UstMenu.do?metod=temelist

[28] TURKSTAT. 2013. Turkish Statistical Institute. Retrieved from http://www.turkstat.gov.tr/UstMenu.do?metod=temelist (Erişim tarihi: 16.11.2016). 